\title{
TOXIC EFFECTS OF THREE SELECTED MALAYSIAN TIMBERS PLANT EXTRACTS AGAINST SUBTERRANEAN TERMITES
}

\author{
Roszaini Kadir ${ }^{1, \text { s }}$
}

\begin{abstract}
The toxic effects of selected Malaysian timbers (Madhuca utilis, Anisoptera laevis and Endospermum malaccense) heartwood extracts were studied with the aim to determine and understanding the function of wood extracts as a natural protection against termite. The results show that no-choice experiments revealed toxic properties of all investigated extracts by the contact against Coptotermes gestroi and Coptotermes curvignathus. However, high termite mortality was only achieved with Madhuca utilis extracts and methanol solvents.
\end{abstract}

Keywords: Madhuca utilis, Anisoptera laevis, Endospermum malaccense, wood extractives, antitermitic activity, Coptotermes gestroi, Coptotermes curvignathus.

\section{INTRODUCTION}

Extractives are low molecular weight compounds that can be extracted by polar or non-polar solvents and encompass complex, and had diverse physical properties (Fengel and Wegener 1989). Because of this, many different solvents and mixtures have been used for extraction. Solvents such as hexane and acetone/water mixtures have been used with some tropical timbers (Kilic and Niemz 2010); methanol and hexane with Azadirachta excelsa (Ahmad Said et al. 2006) and ethanol-benzene with Shorea ovalis and Neobalanocarpus heimii (Ahmad-Said and Mohd-Hamami 1982). In addition, structure, distribution and quantity of secondary metabolites are useful markers for chemotaxonomy (Banthorpe et al. 1972).

It is known that wood extracts are a major contributory factor in the natural durability of the wood (Scheffer and Cowling 1966, Hillis 1987). Many studies (Carter et al. 1975, Steller and Labosky 1982, Chang et al. 2001, Chang and Cheng 2002, Watanabe et al. 2005, Elango et al. 2012, Roszaini et al. 2014, Roszaini et al. 2015) show some promising result on wood extractive against termites. They found that bark and Heartwood extractives exhibited antitermitic activity in a certain percentage of concentrations. Meanwhile, Arango et al. (1992) reported that several advantages can be obtained from the application of wood extractives as wood preservatives. It is relatively safer than synthetic preservative, but still effective. It is Barnes (1992) also easier to detoxify and dispose off without adverse environmental effects because it's the organic based materials.

${ }^{1}$ Biocomposite and Wood Protection Programme, Forest Product Division, Forest Research Institute Malaysia (FRIM), Selangor, Malaysia.

•Corresponding author: roszaini@frim.gov.my

Received: 20.12.2016 Accepted: 11.06.2017 
In some instances, it is only present in small amounts (3 to 6\% of oven-dry weight) (Rudman 1965 , Mori et al. 1997, Reyes-Chilpa et al. 1998, Celimene et al. 1999, Windeisen et al. 2002, Haupt et al. 2003, Neya et al. 2004, Mburu et al. 2007). In other cases, Roszaini (2011) found in her study that this value can achieve up to $15 \%$ (of oven-dry weight) for heartwood and to $35 \%$ (of oven-dry weight) for bark of tropical timbers.

Phenolic compounds, terpenes, carbohydrates, long-chain fatty acids, waxes and other substances, including steryl esters and sterols are among the mainly chemical compounds in heartwood extractives (Fengel and Wegener 1989). Many single or groups of extraneous compounds are known to inhibit the activities of biological agents. For example, sesquiterpenes possess a wide spectrum of biological activity, playing a role in plant defense mechanisms against insects and fungi (Fraga 2003, Wu et al. 2005 ) and, pinosylvin and pinosylvin-monomethyl-ether have been found toxic to fungi (the Sirex fungus, presumably Amylostereum sp.) (Hillis and Inoue 1968).

Meanwhile, Madhuca utilis (Ridley) H.J. Lam ex K. Heyne known as bitis (local name) is one of the large trees which can achieve up to $50 \mathrm{~m}$ in height, $1 \mathrm{~m}$ in diameter and $2 \mathrm{~m}$ high of buttresses (Orwa et al. 2009). It belongs to the family of Sapotaceae and classified as heavy hardwood with a density of $820-1,120 \mathrm{~kg} / \mathrm{m}^{3}$ air dry (Lim et al. 1998).

Anisoptera laevis (Ridl) which is also known as merawan under Malaysian common name is an evergreen tree with a relatively small crown. The tree belongs to the family of Dipterocarpaceae and locally distributed in lowland primary forest of Peninsular Malaysia (Ken 2014). The timber is a medium hardwood with a density of $495-980 \mathrm{~kg} / \mathrm{m}^{3}$ air dry. Its wood is hard and heavy, and particularly used for bridge, rafters, joists, door and window frames, flooring, joinery, furniture manufacture, veneer and plywood manufacture (Wood identification 2010).

Endospermum malaccense Miq. (sesendok) is a timber belonging to the family of Euphorbiaceae. It can be found in lowland to low-Montane forest (up to $1000 \mathrm{~m}$ altitude) and in all states of Peninsular Malaysia (except Perlis) (Mohd Shukari 1982). It's also one of the timber species that has been proposed for plantation in Peninsular Malaysia as an alternative timber species to rubberwood with an excellent working and nailing properties (Ahmad Zuhaidi et al. 2002, Khairul et al. 2010).

However, to the best of our knowledge, a study of the wood extracts of M. utilis, A. laevis and E. malaccense extracted with different solvent from Malaysia, or any other country, has not been reported to date. One study done by Roszaini et al. (2014) shows some promising as antitermitic of M. utilis when extract with toluene/EtOH but, they do not include other solvents in their study. In another study, methanol extraction of $E$. malaccense showed highest antifungal activity against a white-rot fungus, Pycnoporus sanguineus, at a minimum effective amount of $100 \mu \mathrm{g}$ (Kawamura et al. 2011). No single study was done for $E$. malaccense and A. laevis wood extracts against termite. On the other hand, studies (Naczk and Shahidi 2004, Spigno et al. 2007, Kajdžanoska et al. 2011, Lolita et al. 2012) have shown that different solvent extracts different compounds. Based on their studies, it is very important to find the best solvents for extraction of these compounds from plants especially for tropical timbers.

The objective of this paper is to investigate the effects of different solvent extractions on some wood species with respect on the feeding behavior of the two Asian subterranean termites Coptotermes gestroi and C. curvignathus. Although M. utilis, A. laevis and E. malaccense have been reported in durable, moderate and non-durable class timbers respectively, its antitermitic activity has not been tested. So this would be the first study of the antitermitic activity of crude extract of different Malaysian wood species against the two aggressive Asian subterranean termites.

\section{MATERIALS AND METHODS}

\section{Plant material}

Heartwood of three Malaysian timbers: Madhuca utilis (Ridl.) H.J.Lam (bitis), Anisoptera laevis (Ridl) (merawan) and Endospermum malaccense Miq. (sesendok) were cut from felled trees stored in 
the FRIM log yard.

\section{Termite}

Two subterranean termites, Coptotermes gestroi Wasmann and C. curvignathus Holmgren (Isoptera: Rhinotermitidae), were collected from active field colonies at the Forest Research Institute Malaysia (FRIM) campus using a method described before (Roszaini et al. 2009).

\section{Wood block bioassay against subterranean termites}

The un-extracted or had previously been extracted (extracted for 8 hours in an orbital shaker) wood blocks ( $25 \mathrm{~mm} \times 25 \mathrm{~mm} \times 6 \mathrm{~mm}$ ) were subjected to no choice feeding tests according to ASTM D3345-08 (ASTM 1988) standard methods with slightly modified. Rubberwood (Hevea brasiliensis) were used as controls.

Table 1. Classification of natural durability of wood against termites (ASTM D3345, 1988).

\begin{tabular}{|l|c|}
\hline Block aspect after test & Classifications \\
\hline Sound, surface nibbles permitted & 10 \\
\hline Light attack & 9 \\
\hline Moderate attack, penetration & 7 \\
\hline Heavy & 4 \\
\hline Failure & 0 \\
\hline
\end{tabular}

Screw-top bottles of $8 \mathrm{~cm}$ in diameter by $13 \mathrm{~cm}$ high were filled with $200 \mathrm{~g}$ of sterilized sand and $30 \mathrm{ml}$ distilled water. The bottles were left overnight to equilibrate to laboratory conditions before test initiation. One block of each timber species were placed on the surface of the damp sand and 400 termites (360 workers and 40 soldiers) were added to each bottle. All bottles were stored in an incubator maintained at $22 \pm 2^{\circ} \mathrm{C}$ and $65 \pm 5 \%$ relative humidity for 28 days. Within this period, if it was found that all termites appeared dead, the bottle would be taken out and the number of days until $100 \%$ mortality would be recorded. At the end of the fourth week the blocks were removed, cleaned, dried overnight and reweighed. The remaining live termites were weighed and recorded for each of the bottles. Then the wood blocks were classified according to the standard method used (Table 1).

\section{Extraction and isolation}

All the heartwood timber species were ground to fine sawdust powder, passed through a 250 mesh sieve and dried at $60^{\circ} \mathrm{C}$ (to avoid the possibility of extracts degradation) before extraction. About $50 \mathrm{~g}$ of wood sawdust was extracted with four different solvents [absolute methanol $(\mathrm{MeOH})$, absolute ethanol $(\mathrm{EtOH})$, acetone and petroleum ether (PETETHR)] for 8 hours used an orbital shaker (Gallenkamp, UK). The extracts were concentrated under reduced pressure at $45^{\circ} \mathrm{C}$, using a rotary evaporator (EYELA, SB-651, Rikakikai Co. Ltd. Tokyo, Japan) and stored in a refrigerator $\left(-4^{\circ} \mathrm{C}\right)$, until used for analyses. Weight losses of samples were calculated from the oven dry weights at $60^{\circ} \mathrm{C}$ ( 48 hours) before and after the extraction. Retention of extractive material was calculated $\left(\mathrm{mg} / \mathrm{m}^{3}\right)$ as follows:

$$
\mathrm{R}=\left(\mathrm{M}_{1}-\mathrm{M}_{0}\right) \times \mathrm{C}
$$


where, $M_{1}$ is weight after treatment $(\mathrm{g}), \mathrm{M}_{0}$ is a weight before treatment $(\mathrm{g}), \mathrm{C}$ is concentration levels of solutions and $\mathrm{V}$ is volume of filter paper $\left(\mathrm{m}^{3}\right)$. The extractive retentions $\left(\mathrm{mg} / \mathrm{m}^{3}\right)$ in treating filter paper as calculated by solution uptake are presented in Table 2.

Table 2. Mean extractive retentions $\left(\mathrm{mg} / \mathrm{m}^{3}\right)$ in treated filter paper as calculated by solution uptake.

\begin{tabular}{|c|c|c|c|c|}
\hline \multirow{3}{*}{ Solvent } & \multirow{2}{*}{ Concentrations } & \multicolumn{3}{|c|}{ Species/ Retention $\left(\mathrm{mg} / \mathrm{m}^{3}\right)$} \\
\cline { 2 - 5 } & & M. utilis & A. laevis & E. malaccense \\
\hline \multirow{4}{*}{ Methanol } & 0,5 & $0,38(0,25)$ & $1,78(0,26)$ & $0,95(0,25)$ \\
\cline { 2 - 5 } & 1,0 & $1,21(0,10)$ & $2,80(0,72)$ & $2,19(0,38)$ \\
\cline { 2 - 5 } & 2,0 & $4,38(1,06)$ & $6,15(2,49)$ & $3,84(0,38)$ \\
\cline { 2 - 5 } & 3,0 & $8,23(2,06)$ & $6,26(3,36)$ & $7,41(0,99)$ \\
\hline \multirow{5}{*}{ Ethanol } & 4,0 & $10,10(2,12)$ & $9,44(1,37)$ & $9,44(1,01)$ \\
\cline { 2 - 5 } & 0,5 & $1,07(0,14)$ & $0,93(0,17)$ & $0,93(0,26)$ \\
\cline { 2 - 5 } & 1,0 & $2,52(1,25)$ & $1,92(0,41)$ & $1,87(0,10)$ \\
\cline { 2 - 5 } & 2,0 & $5,93(0,87)$ & $4,17(1,48)$ & $3,40(0,50)$ \\
\hline \multirow{5}{*}{ PETETHR } & 3,0 & $7,41(0,86)$ & $5,27(0,75)$ & $7,08(2,06)$ \\
\cline { 2 - 5 } & 4,0 & $9,00(2,66)$ & $7,24(0,66)$ & $8,56(0,66)$ \\
\cline { 2 - 5 } & 0,5 & $0,82(0,36)$ & $0,38(0,10)$ & $0,60(0,41)$ \\
\cline { 2 - 5 } & 1,0 & $2,03(1,19)$ & $0,99(0,33)$ & $0,99(0,16)$ \\
\cline { 2 - 5 } & 2,0 & $2,85(0,95)$ & $1,65(0,00)$ & $1,43(0,83)$ \\
\hline \multirow{5}{*}{ Acetone } & 3,0 & $4,61(2,06)$ & $2,30(0,75)$ & $1,81(0,57)$ \\
\cline { 2 - 5 } & 4,0 & $5,71(3,04)$ & $3,07(0,38)$ & $2,85(0,38)$ \\
\cline { 2 - 5 } & 0,5 & $1,10(0,05)$ & $1,06(0,05)$ & $0,96(0,55)$ \\
\cline { 2 - 5 } & 1,0 & $1,98(0,33)$ & $1,87(0,41)$ & $1,70(0,25)$ \\
\cline { 2 - 5 } & 2,0 & $3,51(0,50)$ & $2,41(2,47)$ & $2,83(1,87)$ \\
\hline & 3,0 & $5,27(0,29)$ & $3,82(0,29)$ & $3,27(1,87)$ \\
\hline
\end{tabular}

Note: Mean of five replicates, numbers in parentheses are standard deviations.

\section{Antitermitic bioassay (Toxicity determination)}

The bioassay method used by previous studies (Roszaini et al. 2013) with slightly modified was used to evaluate the antitermitic activity of wood extracts against $C$. gestroi and $C$. curvignathus.

Samples of 5,0 mg, $10 \mathrm{mg}, 20 \mathrm{mg}, 30 \mathrm{mg}$ and $40 \mathrm{mg}$ of wood extract from four different wood species were dissolved in $100 \mu \mathrm{l}$ of $\mathrm{MeOH}$ to obtain solutions (m/v) of $0,5 \% ; 1,0 \% ; 2,0 \% ; 3 \%$ and $4 \%$, respectively. Then $20 \mu \mathrm{l}$ of the solutions were applied to each $30 \mathrm{mg}$ filter paper samples (Advantec, $8 \mathrm{~mm}$ diameter and $1,5 \mathrm{~mm}$ thickness) and dried in vacuum desiccators for 24 hours. The paper discs were weighed before and after drying. Untreated paper discs were used as a control. 20 active termite workers were introduced into each Petri dish $(90 \mathrm{~mm}$ diameter and $16 \mathrm{~mm}$ height $)$ which contained 3 $\mathrm{g}$ of sterile sand. A few drops of water were added periodically to the basal edge of each Petri dish. All the Petri dishes with covers were placed into an incubator (maintained in darkness) at $22 \pm 2^{\circ} \mathrm{C}$ and $65+5 \% \mathrm{RH}$ and the mortality of the termites was counted and recorded every 24 hours for 10 days. Each test contained 5 replicates including the control. The consumption of the filter papers was calculated from the difference in dry weights before and after the exposure. A dose-mortality line was developed depends on the exposure time $(\mathrm{s})$ and the lethal concentration $\left(\mathrm{LC}_{50}\right)$ of wood extracts was determined using the probit method (Finney 1971).

\section{Statistical analysis}

One way analysis of variance (ANOVA) was performed on all data to determine the significance of variation in extracting compounds and antitermitic between wood species as well as between samples using MINITAB 15 computer programme. The $\mathrm{LC}_{50}$ values were determined directly from probit 
analysis or calculated by substituting $50 \%$ for " $y$ " into the curve equation in the graph.

\section{RESULTS AND DISCUSSION}

\section{Extractives yield}

The quantities of extractive yield of three tropical timber species are presented in Table 3 . Table 3 shows that $\mathrm{MeOH}$ yielded greater amounts of extractive than the other three solvents (EtOH, PETETHR and acetone) in all timber species. M. utilis were classified as durable timbers under Malaysian grading rules (Lim et al. 1998), yielded significantly more extractive $(7,00 \%)$ than the moderately durable $(A$. laevis) $(3,44 \%)$ and non-durable (E. malaccense) $(0,72 \%)$ timbers, in $\mathrm{MeOH}$ use the shaker method. The same pattern also occurred when EtOH $(5,21 \% ; 2,98 \%$ and $0,28 \%$ respectively) and acetone $(3,25 \%$; $1,67 \%$ and $0,44 \%$ respectively) were used. However, A. laevis yielded more $(1,29 \%)$ compared to $M$. utilis $(0,13 \%)$ and E. malaccense $(0,30)$ when PETETHR was used. As indicated by several authors (Chang et al. 2001, Syofuna et al. 2012, Ogunwusi et al. 2013), extracts which are low molecular weight compounds in the wood can be extracted by many solvents. However, they differ among timber species, between individual tree of the same species and solvents (Scheffer and Cowling 1966, Nacimento et al. 2013) due to genetic variation and environmental (Ericsson et al. 2001). Furthermore, solvent polarity plays a key role in determining the extract yields to be obtained (Bashash et al. 2012). On the other hand, shaker method is not a good method with respect to extraction efficiency for plant materials. As indicated by a few studies before (Park et al. 2001, Kothari et al. 2012), a heat-employing methods' (soxhlet) proved to be the best option for extraction any plant materials.

In another study, even though $\mathrm{MeOH}$ is indeed the most common and effective solvent, it has been reported is an environmental pollutant and more toxic than other alcohols (Kapasakalidi et al. 2006, Bridgers et al. 2010). Thus EtOH is preferred as solvent extraction (Delgado-Vargas and ParedesLopez 2002).

Table 3. Effect of different solvent extraction on extractive yields of three wood species.

\begin{tabular}{|l|c|c|c|c|}
\hline \multirow{2}{*}{ Wood species } & \multicolumn{4}{|c|}{ Extractive yields (\%) } \\
\cline { 2 - 5 } & Methanol & Ethanol & Petroleum ether & Acetone \\
\hline M. utilis & $7,00^{\mathrm{a}}$ & $5,21^{\mathrm{b}}$ & $0,13^{\mathrm{d}}$ & $3,25^{\mathrm{c}}$ \\
\hline A. laevis & $3,44^{\mathrm{a}}$ & $2,98^{\mathrm{b}}$ & $1,29^{\mathrm{d}}$ & $1,67^{\mathrm{cd}}$ \\
\hline E. malaccense & $0,72^{\mathrm{a}}$ & $0,28^{\mathrm{c}}$ & $0,30^{\mathrm{bc}}$ & $0,44^{\mathrm{b}}$ \\
\hline
\end{tabular}

Note: Means with the same letters are not significantly different at $95 \%$ confidence limit.

\section{Bioassay test against termites}

\section{Termite mortality}

Among the three timber species tested, M. utilis heartwood samples were very resistant to attack by both subterranean termite; $C$. gestroi and $C$. curvignathus. Daily assessment shows that majority of the termite in M. utilis test bottles died within 15 days compared to 18 days in A. laevis and more longer (26 days) in E. malaccense test bottles. Result from this study shows that all castes of termite used (workers and soldiers) either in C. gestroi or C. curvignathus completely died in all M. utilis extracts. A. laevis extracts using PETETHR showed $1,0 \%$ and $0,05 \%$ while $E$. malaccense extracts using $\mathrm{MeOH}$ showed $0,08 \%$ and $0,02 \%$ of workers surviving for $C$. gestroi and C. curvignathus, respectively. Surprisingly, E. malaccense EtOH extracts showed 1,22\% of $C$. gestro $i$ workers surviving at the end of the test. All termites also $100 \%$ died when tested with unextracted samples of M. utilis and A. laevis but showed minimal survival (0,01\% against $C$. gestroi and $0,005 \%$ against $C$. curvignathus, respectively) in unextracted E. malaccense samples. Higher survival occurred in brasiliensis test bottles $(2,1 \%$ 
against $C$. gestroi and 2,8\% against $C$. curvignathus). Even though the mortality percentages due to the used wood of extracts were not significantly different from control (brasiliensis), suggesting the toxic effect of these three timber species wood extracts against termites.

The results of termite mortality could be the reaction of termites to the toxic, anti-feeding and / or repellent effects (Yuan and $\mathrm{Hu} 2011$ ). In all cases, higher termite mortality exists when exposed to un-extracted samples compared to extracted indicates the function of heartwood extractives as a natural wood preservative against termites (Syofuna et al. 2012, Tascioglu et al. 2012, Kirker et al. 2013). In other words, wood extracts are one of the factors that increase the termite mortality.

On the other hand, the results, evidently indicate that $M$. utilis heartwood extractives contain biologically active compounds that were potent to $C$. gestroi and C. curvignathus. $\mathrm{MeOH}$ apparently was a better solvent in extracting the toxic chemical compounds followed by $\mathrm{EtOH}$, acetone and PETETHR. M. utilis extract completed the mortality of $C$. gestroi and C. curvignathus at the concentration of $4 \%$ compared to A. laevis and E. malaccense even though there was not much difference between C. curvignathus and C. gestroi mortality in every concentration. $\mathrm{MeOH}$ extracts that killed both termite species tested may have reacted and made a food substrate to be toxic to both termite species. Golpayegani et al. (2014) in their study on mulberry wood (Morus alba) extractives against Reticulitermes flavipes also found that $\mathrm{MeOH}$ is the second best solvent besides acetone that give a low termite survival. On the other hand, Syofuna et al. (2012) reported that different compounds obtained from different solvents will show a different effect towards termite resistance. In conclusion of Taylor et al. (2006) study, to understand the natural durability of wood against termites, we can't just focus on a single compound alone, but this resistance is a combination of several compounds that are present in the wood.
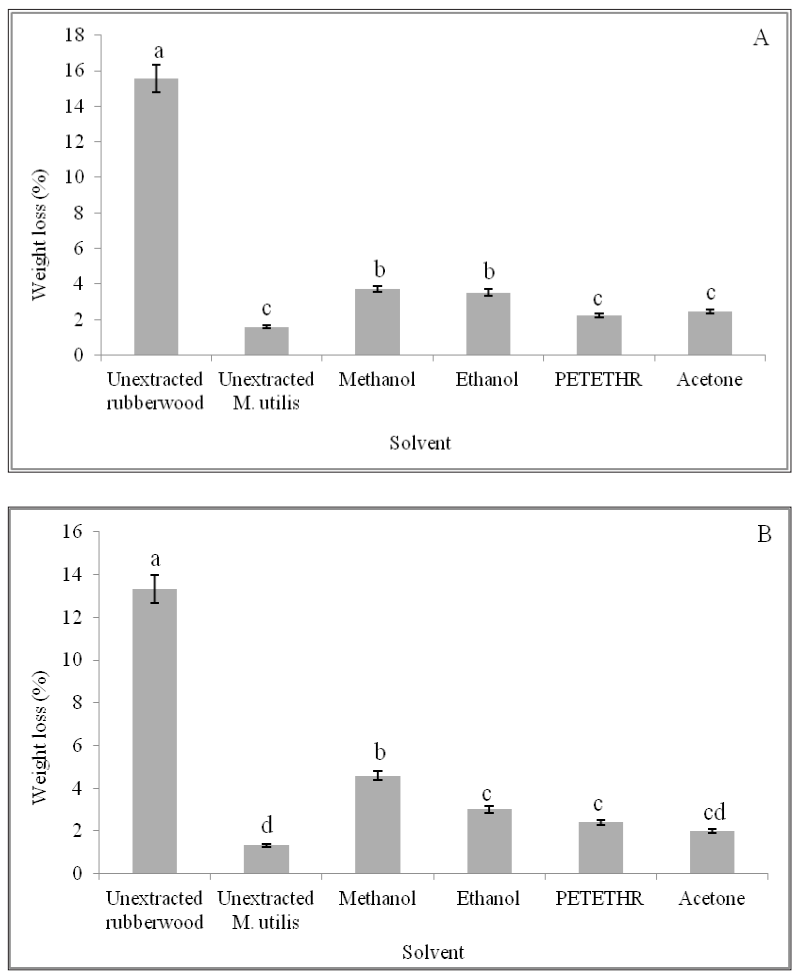

Figure 1. Weight loss of $M$. utilis extracted in selective solvents and exposed for 4 weeks to A: C. gestroi and B: C. curvignathus blocks that were subjected to various extraction procedures. Columns with the same letter are not significantly different at $\alpha=0,05$. 

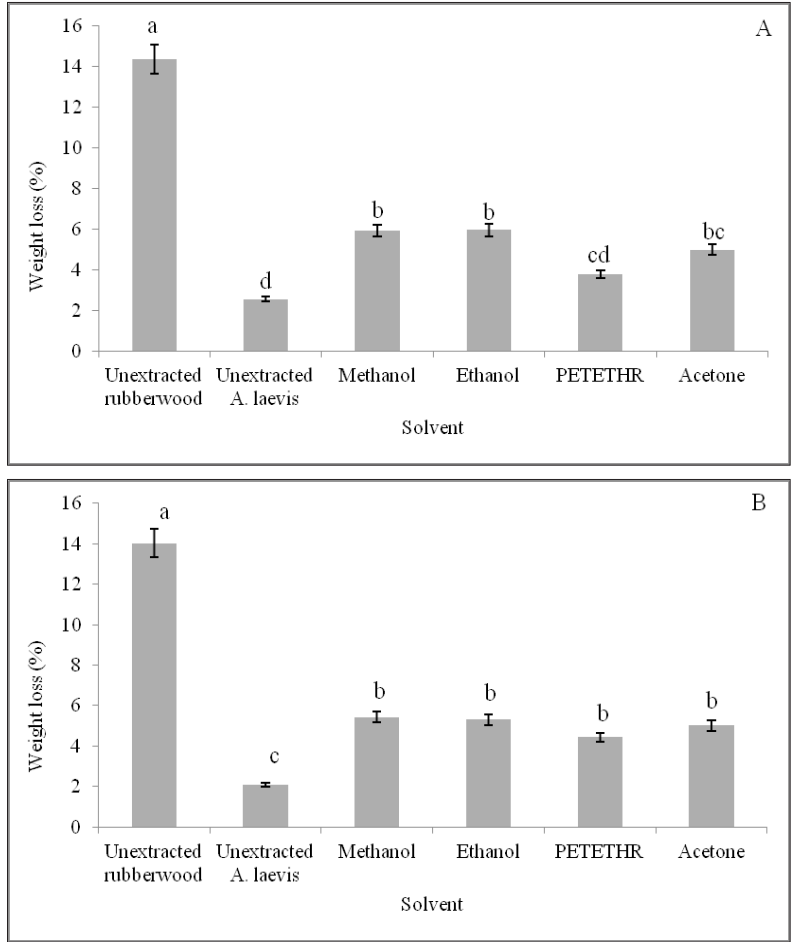

Figure 2. Weight loss of A. laevis extracted in selective solvents and exposed for 4 weeks to A: C. gestroi and B: C. curvignathus of blocks that were subjected to various extraction procedures.

Columns with the same letter are not significantly different at $\alpha=0,05$.
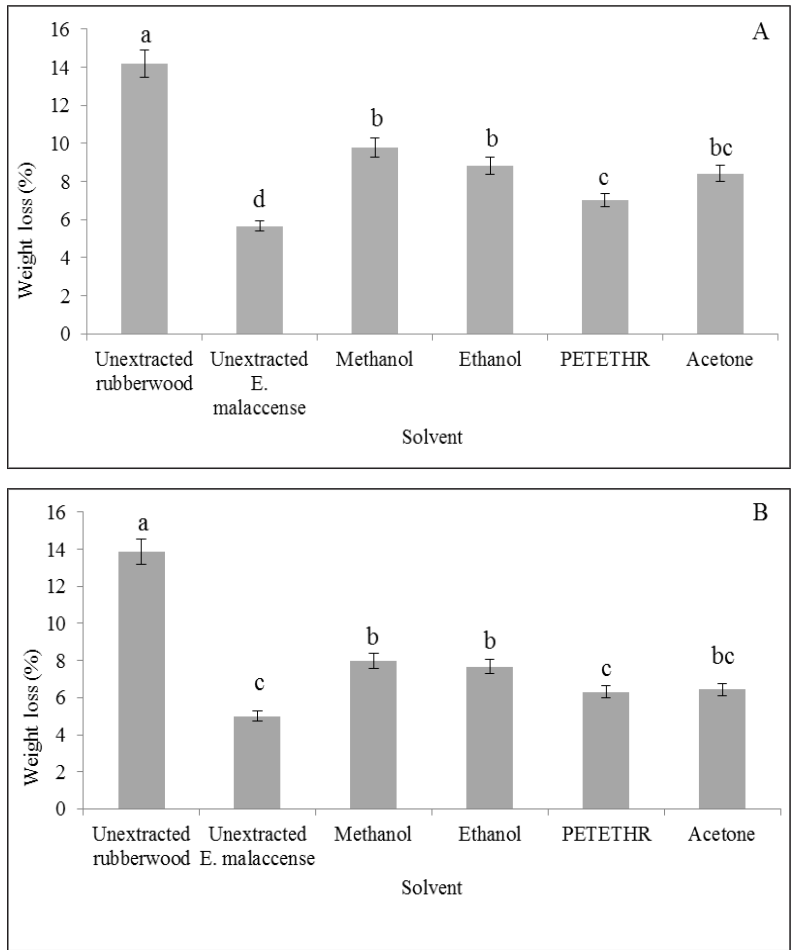

Figure 3. Weight loss of E. malaccensis extracted in selective solvents and exposed for 4 weeks to A: C. gestroi and B: C. curvignathus of blocks that were subjected to various extraction procedures. Columns with the same letter are not significantly different at $\alpha=0,05$. 


\section{Weight loss}

Figure 1, Figure 2 and Figure 3 reports the effects of the different extracts on the feeding behavior of two different subterranean termite species. The result of no-choice termite bioassays also shows that extracted blocks gave a higher wood consumption compared with un-extracted blocks in all wood species tested. Both termite species consumed more wood on un-extracted E. malaccense samples (5,66\% against $C$. gestroi and 5,01\% against $C$. curvignathus, respectively) than the other two timber species; M. utilis (1,58\% against $C$. gestroi and 1,33\% against $C$. curvignathus, respectively) and $A$. laevis (2,57\% against $C$. gestroi and 2,09\% against $C$. curvignathus, respectively). Indirectly, these results suggest that $M$. utilis heartwood is more resistant to both termites than the other two timber species. E. malaccense extracted blocks had the highest mass loss at all solvent used $[\mathrm{MeOH}-9,78 \%$, EtOH $-8,84 \%$ PETETHR $-7,01 \%$ and acetone $-8,41 \%$ against $C$. gestroi and $\mathrm{MeOH}-8,00 \%$, EtOH $-7,68 \%$ PETETHR $-6,31 \%$ and acetone $-6,44 \%$ against $C$. curvignathus (Figure 3)] whereas $M$. utilis extracted blocks had the lowest weight loss [MeOH - 3,71\%, EtOH - 3,52\% PETETHR - 2,22\% and acetone $-2,44 \%$ against $C$. gestroi and $\mathrm{MeOH}-4,59 \% \mathrm{EtOH}-3,01 \%$ PETETHR $-2,40 \%$ and acetone $-1,98 \%$ against $C$. curvignathus (Figure 1 ).

In all cases, a significant effect was observed on the weight loss of wood blocks against $C$. gestroi. All solvents (MeOH, EtOH, acetone and PETETHR) lead to similar trends on the two termites tested (except M. utilis against C. gestroi), probably indicating the presence of the same molecules. Both species of termites also show a similar trend in wood weight loss. However, the performance of wood durability for each timber species depends on the type of solvent used. As reported by González-Laredo et al. (2015), both quantity and particularly the quality of extractives have a key role, but their relative contribution varies considerably from substrate to substrate. On the other hand, studies have shown that extracts of wood is the important factor that determine the durability of wood. This agreed with the study done by Roszaini and Hale (2012) on twelve species of tropical timbers against $C$. curvignathus and C. gestroi. They found that timbers with high extractive content had high termite resistance and species with lower extractive content showed poor performance. In addition, Lapornik et al. (2005) reported that different solvent extracts different chemical compound. The differences also could be due to the properties of the phenolic components of the plants concerned.

\section{Antitermitic bioassay}

The result of antitermitic activities of wood extract is depicted in Table 4, Table 5 and Table 6. The antitermite functions were dependent on the chemical composition of the wood extracts. Previous study indicates that $M$. utilis extracts under varied concentrations inhibit termite feeding. Similarly, $M$. utilis extracts showed the strongest anti-termitic activities against $C$. gestroi and $C$. curvignathus (Roszaini et al. 2014). It is evident from an earlier study that constituents of wood extracts could affect their anti-termite activity; some influenced greater potency while some others lower, e. g. Monoterpene hydrocarbon possessed lower anti-termite activity as compared with oxygenated constituents (Watanabe et al. 2005, Roszaini et al. 2014).

Table 4, Table 5 and Table 6 indicated that heartwood extracts of M. utilis had more anti-termitic activities against both subterranean termites; $C$. gestroi and $C$. curvignathus than A. laevis and $E$. malaccensis. The percentage of paper consumption was $1,01 \%$ (MeOH extracts), $1,37 \%$ (EtOH extracts), 1,92\% (PETETHR extracts) and 1,68\% (acetone extracts) at the concentration of $4 \%$ against C. gestroi while it was $1,15 \% ; 2,24 \% ; 2,11 \%$ and $1,72 \%$ respectively, for $A$. laevis and $1,66 \% ; 2,34 \%$; $2,38 \%$ and 2,27\%; respectively, for E. malaccensis. The same trend (M. utilis extracts) also occurs on tests against $C$. curvignathus.

Table 4, Table 5 and Table 6 reveal that there was a significant increase in the number of termites in contact with the solvent control disc in comparison to the number of termites on the corresponding extract-treated disc $(P<0,05 ; \mathrm{DF}=5)$ for all wood extracts tested. The current study demonstrated that all four concentrations of the heartwood extract from three different timber species were less preferred and avoided by the both subterranean termite, $C$. gestroi and C. curvignathus. Lower percentage of paper consumption was obtained at the highest concentration (4\%) of every solvent extracts compared to $0,5 \%$ of the minimum concentration, respectively. This trend is the same for both termite species 
tested. According to the statistical analyses, lower concentration levels $(0,5 \%)$ of all timber extracts resulted in significant reductions in weight loss when compared to the untreated controls.

Extracts from all timber tested strongly inhibited termite feeding against $C$. gestroi and $C$. curvignathus although E. malaccensis heartwood extracts were much less than M. utilis and A. laevis extracts. M. utilis heartwood extracts with $\mathrm{MeOH}$ solvents is the most active against both termite species at any level of concentration. At $0,5 \%$ level of concentration of any solvent used, M. utilis extracts inhibited $\sim 1,5$-fold (against $C$. gestroi) and $\sim 1,3$-fold (against $C$. curvignathus) than $A$. laevis the heartwood extracts and $\sim 2,0$-fold and $\sim 2,3$-fold than E. malaccensis, respectively. At the highest level of concentration (4,0\%) also in any solvent used, $M$. utilis extracts inhibited $\sim 1,3$-fold (against $C$. gestroi) and $\sim 1,5$-fold (against C. curvignathus) than A. laevis heartwood extracts and $\sim 1,8$-fold and $\sim 2,0$-fold than E. malaccensis, respectively. The strong feeding inhibition from M. utilis heartwood extractives could be due to the higher value of monoterpenes and sesquiterpenes groups where both are interfering with basic behavioural functions of insects (Werner and Illmann 1994, Roszaini et al. 2014). As indicated by other studies, the presence of flavonoids (Ohmura et al. 2000, Wang et al. 2004) and quinones (Nacimento et al. 2013) which possess natural repellent and toxic properties will also increase the durability of the timber against termites.

Findings suggested that all wood extracts may produce larvicidal effects (behaving like general toxicants) against both termites; C. gestroi and C. curvignathus but depends on the solvents used. Laboratory bioassay of $M$. utilis against both subterranean workers showed that the $\mathrm{LC}_{50}$ value of $C$. gestroi was higher than $C$. curvignathus in all solvents used. Numerical $\mathrm{LC}_{50}$ values differed based on solvent used $\left(\mathrm{MeOH}>\mathrm{EtOH}>\right.$ Acetone $>$ PETETHR). The $\mathrm{LC}_{50}$ of M. utilis heartwood $\mathrm{MeOH}$ extracts was $8,86 \%$ for $C$. gestroi and $8,51 \%$ for C. curvignathus, $9,17 \%$ and $8,98 \%$ for EtOH extracts $10,24 \%$ and $10,01 \%$ for PETETHR and $9,79 \%$ and $9,50 \%$ for acetone extracts, respectively (Table 4 ). Same trend also exists in E. malaccensis except with PETETHR solvents. The $\mathrm{LC}_{50}$ for E. malaccensis was $10,35 \%$ for $C$. gestroi and $9,88 \%$ for C. curvignathus when using $\mathrm{MeOH}$ as a solvent $11,42 \%$ and $10,85 \%$ for EtOH, $11,14 \%$ and 11,66 for PETETHR and $13,31 \%$ and $12,67 \%$ for acetone, respectively (Table 6). Contrarily, with M. utilis and E. malaccensis, the $\mathrm{LC}_{50}$ result of A. leavis heartwood extract against $C$. curvignathus was higher than $C$. gestroi (except when using $\mathrm{MeOH}$ solvents). The $\mathrm{LC}_{50}$ values of $\mathrm{MeOH}$ solvents were $9,79 \%$ for C. gestroi and 9,15\% for C. curvignathus, $10,34 \%$ and $11,98 \%$ for EtOH, $11,52 \%$ and $11,88 \%$ for PETETHR and $9,82 \%$ and $10,11 \%$ for acetone, respectively (Table 5). The lowest of $\mathrm{LC}_{50}$ values of $\mathrm{MeOH}$ extracts followed by $\mathrm{EtOH}$ and acetone compared to PETETHR solvents could be to the phenolic content that they extracted. Phenolic content is one of the chemical constituents that influenced the rate of degradation. The higher the total phenolic content, the higher resistivity of the wood species. This means that only low concentrations necessary to turn off at least $50 \%$ of the number of termites (Shanbhag and Sundararaj 2013). 
Table 4. Effect of M. utilis wood extracts on feeding and mortality of C. gestroi and C. curvignathus.

\begin{tabular}{|c|c|c|c|c|c|c|c|}
\hline \multirow{2}{*}{ Treatment } & \multirow{2}{*}{$\begin{array}{l}\text { Con. } \\
(\%)\end{array}$} & \multicolumn{2}{|c|}{$\%$ paper consumption } & \multicolumn{2}{|c|}{ \% Feeding-Inhibition (FI\%) } & \multicolumn{2}{|c|}{ LC50 (\%) } \\
\hline & & $C G$ & $C C$ & $C G$ & $C C$ & $C G$ & $C C$ \\
\hline Control & & $6,382(0,35)^{\mathrm{a}}$ & $6,015(0,46)^{\mathrm{a}}$ & & & & \\
\hline \multirow{6}{*}{ Methanol } & & $4,891(0,66)^{\mathrm{b}}$ & $4,282(0,80)^{b}$ & & & & \\
\hline & 0,5 & $2,444(0,38)^{\mathrm{c}}$ & $2,533(0,52)^{\mathrm{c}}$ & $55,21(2,39)^{\mathrm{d}}$ & $59,88(1,85)^{\mathrm{d}}$ & $8,86^{\mathrm{b}}$ & $8,51^{b}$ \\
\hline & 1 & $1,992(0,84)^{\mathrm{d}}$ & $1,844(0,22)^{\mathrm{c}}$ & $68,44(0,12)^{\mathrm{c}}$ & $70,44(0,88)^{\mathrm{c}}$ & & \\
\hline & 2 & $1,787(0,56)^{\mathrm{d}}$ & $1,109(0,19)^{\mathrm{d}}$ & $76,94(2,69)^{b}$ & $78,36(0,11)^{\mathrm{b}}$ & & \\
\hline & 3 & $1,554(0,22)^{\mathrm{de}}$ & $0,927(0,22)^{\mathrm{d}}$ & $79,52(1,44)^{\mathrm{ab}}$ & $85,64(1,35)^{\mathrm{ab}}$ & & \\
\hline & 4 & $1,012(0,11)^{\mathrm{e}}$ & $0,772(0,45)^{\mathrm{d}}$ & $82,38(0,09)^{\mathrm{a}}$ & $89,37(1,35)^{\mathrm{a}}$ & & \\
\hline Control & & $6,382(0,35)^{\mathrm{a}}$ & $6,015(0,46)^{\mathrm{a}}$ & & & & \\
\hline \multirow[t]{6}{*}{ Ethanol } & & $5,173(0,27)^{\mathrm{b}}$ & $5,007(0,51)^{\mathrm{b}}$ & & & & \\
\hline & 0,5 & $3,267(1,17)^{\mathrm{c}}$ & $2,863(1,43)^{\mathrm{c}}$ & $50,44(0,22)^{\mathrm{c}}$ & $52,22(1,22)^{\mathrm{c}}$ & $9,17^{b}$ & $8,98^{\mathrm{b}}$ \\
\hline & 1 & $3,014(0,66)^{\mathrm{c}}$ & $2,222(0,05)^{\mathrm{cd}}$ & $55,38(0,08)^{\mathrm{c}}$ & $57,37(0,36)^{\mathrm{c}}$ & & \\
\hline & 2 & $2,447(1,37)^{\mathrm{d}}$ & $1,970(1,11)^{\mathrm{d}}$ & $62,10(2,28)^{b}$ & $70,18(0,64)^{b}$ & & \\
\hline & 3 & $1,633(2,21)^{\mathrm{e}}$ & $1,818(0,44)^{\mathrm{de}}$ & $69,99(0,08)^{\mathrm{ab}}$ & $74,49(1,22)^{\mathrm{ab}}$ & & \\
\hline & 4 & $1,379(0,07)^{\mathrm{e}}$ & $1,220(1,52)^{\mathrm{e}}$ & $76,43(0,09)^{\mathrm{a}}$ & $78,27(1,35)^{\mathrm{a}}$ & & \\
\hline Control & & $6,382(0,35)^{\mathrm{a}}$ & $6,015(0,46)^{\mathrm{a}}$ & & & & \\
\hline \multirow{6}{*}{$\begin{array}{l}\text { Petroleum } \\
\text { ether }\end{array}$} & & $5,487(0,11)^{b}$ & $5,334(1,24)^{b}$ & & & & \\
\hline & 0,5 & $4,111(1,13)^{\mathrm{c}}$ & $3,697(0,07)^{\mathrm{c}}$ & $46,62(2,65)^{\mathrm{c}}$ & $47,34(0,08)^{\mathrm{c}}$ & $10,24^{\mathrm{a}}$ & $10,01^{\mathrm{a}}$ \\
\hline & 1 & $3.339(0.59)^{\mathrm{d}}$ & $3,018(0,27)^{\mathrm{cd}}$ & $50,11(1,12)^{\mathrm{bc}}$ & $50,98(0,65)^{\mathrm{bc}}$ & & \\
\hline & 2 & $2,445(0,91)^{\mathrm{e}}$ & $2,625(0,18)^{\mathrm{de}}$ & $55,33(2,66)^{b}$ & $54,57(0,22)^{b}$ & & \\
\hline & 3 & $2,008(1,00)^{\mathrm{e}}$ & $1,872(0,66)^{\mathrm{e}}$ & $68,21(0,44)^{\mathrm{a}}$ & $69,69(2,64)^{\mathrm{a}}$ & & \\
\hline & 4 & $1,927(0,06)^{\mathrm{e}}$ & $1,671(0,83)^{\mathrm{e}}$ & $70,58(0,58)^{\mathrm{a}}$ & $73,35(3,22)^{\mathrm{a}}$ & & \\
\hline Control & & $6,382(0,35)^{\mathrm{a}}$ & $6,015(0,46)^{\mathrm{a}}$ & & & & \\
\hline \multirow{6}{*}{ Acetone } & & $5,551(0,11)^{b}$ & $5,221(0,03)^{b}$ & & & & \\
\hline & 0,5 & $3,512(1,11)^{\mathrm{c}}$ & $3,421(0,22)^{\mathrm{c}}$ & $48,33(1,66)^{\mathrm{c}}$ & $49,11(1,46)^{\mathrm{c}}$ & $9,79^{\mathrm{ab}}$ & $9,50^{\mathrm{a}}$ \\
\hline & 1 & $3,017(1,09)^{\mathrm{cd}}$ & $2,990(0,33)^{\mathrm{cd}}$ & $50,22(0,88)^{\mathrm{c}}$ & $51,52(0,06)^{\mathrm{c}}$ & & \\
\hline & 2 & $2,455(0,77)^{\mathrm{d}}$ & $2,510(0,52)^{\mathrm{de}}$ & $54,87(0,08)^{\mathrm{c}}$ & $58,88(1,22)^{\mathrm{b}}$ & & \\
\hline & 3 & $2,383(0,06)^{d}$ & $2,077(0,47)^{\mathrm{e}}$ & $62,01(1,35)^{\mathrm{b}}$ & $63,31(1,64)^{b}$ & & \\
\hline & 4 & $1,682(0,05)^{\mathrm{e}}$ & $1,456(0,01)^{\mathrm{e}}$ & $75,37(0,98)^{\mathrm{a}}$ & $77,51(1,64)^{\mathrm{a}}$ & & \\
\hline
\end{tabular}

$\mathrm{CG}=C$. gestroi, $\mathrm{CC}=$ C. curvignathus. Con. $=$ Concentration. Mean $( \pm \mathrm{SD})$ of 5 replicates for each species. Percentage values followed by the same letter are not significantly different in the same group at the 0,05 level of probability. $\mathrm{LC}_{50}=$ Lethal Concentration which causes a $50 \%$ reduction in feeding as compared to the nontreated control. 
Table 5. Effect of A. laevis wood extracts on feeding and mortality of C. gestroi and $C$. curvignathus.

\begin{tabular}{|c|c|c|c|c|c|c|c|}
\hline \multirow{2}{*}{ Treatment } & \multirow{2}{*}{$\begin{array}{l}\text { Con. } \\
(\%)\end{array}$} & \multicolumn{2}{|c|}{$\%$ paper consumption } & \multicolumn{2}{|c|}{$\%$ Feeding-Inhibition (FI\%) } & \multicolumn{2}{|c|}{ LC50 (\%) } \\
\hline & & $C G$ & $C C$ & $C G$ & $C C$ & $C G$ & $C C$ \\
\hline Control & & $6,382(0,35)^{\mathrm{a}}$ & $6,015(0,46)^{\mathrm{a}}$ & & & \multirow{7}{*}{$9,79^{\mathrm{b}}$} & \multirow{7}{*}{$9,15^{\mathrm{c}}$} \\
\hline \multirow[t]{6}{*}{ Methanol } & & $4891(0,66)^{b}$ & $4,284(0,80)^{b}$ & & & & \\
\hline & 0,5 & $4,050(0,23)^{b}$ & $3,893(0,59)^{\mathrm{bc}}$ & $40,39(2,56)^{\mathrm{d}}$ & $45,33(1,12)^{\mathrm{c}}$ & & \\
\hline & 1 & $3,344(0,08)^{\mathrm{c}}$ & $3,342(1,26)^{\mathrm{c}}$ & $45,22(1,13)^{\mathrm{c}}$ & $50,01(2,69)^{\mathrm{b}}$ & & \\
\hline & 2 & $2,593(0,22)^{\mathrm{d}}$ & $3,017(0,85)^{\mathrm{c}}$ & $50,01(1,14)^{\mathrm{c}}$ & $52,33(1,16)^{\mathrm{b}}$ & & \\
\hline & 3 & $1,875(0,44)^{\mathrm{d}}$ & $2,540(2,36)^{\mathrm{d}}$ & $57,35(8,55)^{\mathrm{b}}$ & $56,33(2,25)^{\mathrm{ab}}$ & & \\
\hline & 4 & $1,156(0,22)^{\mathrm{e}}$ & $1,245(0,22)^{\mathrm{e}}$ & $65,71(3,69)^{\mathrm{a}}$ & $60,38(7,14)^{\mathrm{a}}$ & & \\
\hline Control & & $6,382(0,35)^{\mathrm{a}}$ & $6,015(0,46)^{\mathrm{a}}$ & & & & \\
\hline \multirow[t]{6}{*}{ Ethanol } & & $5,174(0,27)^{b}$ & $5,000(0,51)^{\mathrm{b}}$ & & & & \\
\hline & 0,5 & $4,508(0,11)^{\mathrm{b}}$ & $4,144(0,03)^{\mathrm{c}}$ & $35,62(1,12)^{\mathrm{c}}$ & $40,61(2,44)^{\mathrm{b}}$ & $10,34^{\mathrm{ab}}$ & $11,98^{\mathrm{a}}$ \\
\hline & 1 & $3,775(0,67)^{\mathrm{c}}$ & $3,69(2,21)^{\mathrm{cd}}$ & $48,33(0,82)^{\mathrm{b}}$ & $46,46(0,97)^{\mathrm{b}}$ & & \\
\hline & 2 & $2,924(0,43)^{\mathrm{cd}}$ & $3,110(1,92)^{\mathrm{d}}$ & $48,59(0,07)^{\mathrm{b}}$ & $52,38(0,02)^{\mathrm{a}}$ & & \\
\hline & 3 & $2,416(0,52)^{d}$ & $2,598(0,08)^{\mathrm{d}}$ & $51,68(0,65)^{\mathrm{b}}$ & $56,66(1,17)^{\mathrm{a}}$ & & \\
\hline & 4 & $2,248(0,09)^{\mathrm{d}}$ & $1,875(1,47)^{\mathrm{e}}$ & $60,44(2,87)^{\mathrm{a}}$ & $58,53(3,44)^{\mathrm{a}}$ & & \\
\hline Control & & $6,382(0,35)^{\mathrm{a}}$ & $6,015(0,46)^{\mathrm{a}}$ & & & & \\
\hline \multirow{6}{*}{$\begin{array}{l}\text { Petroleum } \\
\text { ether }\end{array}$} & & $5,484(0,11)^{b}$ & $5,332(1,24)^{b}$ & & & & \\
\hline & 0,5 & $4,965(2,25)^{b}$ & $4,627(0,81)^{\mathrm{b}}$ & $32,28(3,34)^{\mathrm{d}}$ & $35,51(1,80)^{\mathrm{c}}$ & $11,52^{\mathrm{a}}$ & $11,88^{\mathrm{a}}$ \\
\hline & 1 & $4,036(1,28)^{\mathrm{c}}$ & $3,882(0,65)^{\mathrm{c}}$ & $38,80(0,44)^{\mathrm{d}}$ & $40,01(1,64)^{\mathrm{bc}}$ & & \\
\hline & 2 & $3,773(0,67)^{\mathrm{c}}$ & $3,267(2,22)^{\mathrm{c}}$ & $43,45(0,65)^{\mathrm{c}}$ & $42,57(1,22)^{b}$ & & \\
\hline & 3 & $2,995(0,09)^{\mathrm{cd}}$ & $2,393(0,98)^{\mathrm{cd}}$ & $47,31(2,29)^{b}$ & $48,88(0,88)^{\mathrm{ab}}$ & & \\
\hline & 4 & $2,115(0,88)^{d}$ & $1,821(0,14)^{d}$ & $51,11(3,12)^{\mathrm{a}}$ & $52,21(4,12)^{\mathrm{a}}$ & & \\
\hline Control & & $6,382(0,35)^{\mathrm{a}}$ & $6,015(0,46)^{\mathrm{a}}$ & & & & \\
\hline \multirow{6}{*}{ Acetone } & & $5,551(0,11)^{b}$ & $5,228(0,03)^{\mathrm{b}}$ & & & & \\
\hline & 0,5 & $4,330(2,27)^{b}$ & $3,982(0,18)^{b}$ & $39,92(0,47)^{\mathrm{c}}$ & $37,74(0,87)^{\mathrm{c}}$ & $9,82^{\mathrm{b}}$ & $10,11^{\mathrm{b}}$ \\
\hline & 1 & $4,010(0,12)^{\mathrm{c}}$ & $3,332(0,53)^{\mathrm{c}}$ & $42,22(1,88)^{\mathrm{bc}}$ & $46,22(1,62)^{b}$ & & \\
\hline & 2 & $3,427(0,04)^{\mathrm{c}}$ & $2,763(0,64)^{\mathrm{c}}$ & $46,36(1,01)^{\mathrm{b}}$ & $48,88(1,25)^{\mathrm{b}}$ & & \\
\hline & 3 & $2,186(0,66)^{\mathrm{cd}}$ & $2,344(0,15)^{\mathrm{cd}}$ & $48,00(2,22)^{b}$ & $52,22(1,11)^{\mathrm{ab}}$ & & \\
\hline & 4 & $1,722(0,72)^{\mathrm{d}}$ & $1,082(0,22)^{\mathrm{d}}$ & $56,81(0,87)^{\mathrm{a}}$ & $59,22(3,39)^{\mathrm{a}}$ & & \\
\hline
\end{tabular}

$\mathrm{CG}=C$. gestroi, $\mathrm{CC}=C$. curvignathus. Con. $=$ Concentration. Mean $( \pm \mathrm{SD})$ of 5 replicates for each species. Percentage values followed by the same letter are not significantly different in the same group at the 0,05 level of probability. $\mathrm{LC}_{50}=$ Lethal Concentration which causes a 50\% reduction in feeding as compared to the nontreated control. 
Table 6. Effect of E. malaccensis wood extracts on feeding and mortality of $C$. gestroi and $C$. curvignathus.

\begin{tabular}{|c|c|c|c|c|c|c|c|}
\hline \multirow{2}{*}{ Treatment } & \multirow{2}{*}{$\begin{array}{l}\text { Con. } \\
(\%)\end{array}$} & \multicolumn{2}{|c|}{$\%$ paper consumption } & \multicolumn{2}{|c|}{ \% Feeding-Inhibition (FI\%) } & & LC50 (\%) \\
\hline & & $C G$ & $C C$ & $C G$ & $C C$ & $C G$ & $C C$ \\
\hline Control & & $6,382(0,35)^{\mathrm{a}}$ & $6,015(0,46)^{\mathrm{a}}$ & & & & \\
\hline \multirow{5}{*}{ Methanol } & & $4,891(0,66)^{b}$ & $4,288(0,80)^{\mathrm{b}}$ & & & & \\
\hline & 0,5 & $4,390(0,64)^{b}$ & $4,641(0,59)^{b}$ & $28,56(3,36)^{\mathrm{b}}$ & $29,33(3,38)^{\mathrm{b}}$ & $10,35^{\mathrm{b}}$ & $9,88^{\mathrm{b}}$ \\
\hline & $\frac{1}{2}$ & $\frac{3,664(0,14)^{b}}{3,033(0,64)^{b c}}$ & $\begin{array}{l}4,017(1,14)^{\circ} \\
3,010(1,11)^{\mathrm{bc}}\end{array}$ & $36,84(0,02)^{\mathrm{ab}}$ & $35,64(7,25)^{\mathrm{ab}}$ & & \\
\hline & 3 & $2,672(0,65)^{\mathrm{bc}}$ & $2,883(0,99)^{\mathrm{bc}}$ & $42,11(5,52)^{a}$ & $43,29(2,26)^{\mathrm{a}}$ & & \\
\hline & 4 & $1,667(0,25)^{\mathrm{c}}$ & $2,089(0,06)^{\mathrm{c}}$ & $48,88(0,08)^{\mathrm{a}}$ & $45,31(1,17)^{\mathrm{a}}$ & & \\
\hline \multirow{6}{*}{$\begin{array}{l}\text { Control } \\
\text { Ethanol }\end{array}$} & & $6,382(0,35)^{a}$ & $6,015(0,46)^{\mathrm{a}}$ & & & & \\
\hline & & $5,170(0,27)^{b}$ & $5,009(0,51)^{b}$ & $2517\left(3,25 b^{b}\right.$ & & $1142^{\mathrm{b}}$ & $1085^{\mathrm{b}}$ \\
\hline & 0,5 & $\frac{4,502(0,11)^{\circ}}{3,773(0,67)^{b}}$ & $\frac{4,144(0,03)^{b}}{3680(222)^{b}}$ & $\frac{25,17(3,25)^{b}}{2999(142) b}$ & $\frac{23,48(2,82)^{b}}{2755\left(202 b^{b}\right.}$ & $11,42^{\circ}$ & $10,85^{\circ}$ \\
\hline & 2 & $2,929(0,43)^{\mathrm{bc}}$ & $3,110(1,92)^{\mathrm{bc}}$ & $30,14(0,56)^{\mathrm{ab}}$ & $29.65(0.64)^{\mathrm{ab}}$ & & \\
\hline & 3 & $2,592(0,08)^{\mathrm{bc}}$ & $2,598(0,08)^{\mathrm{bc}}$ & $40,01(0,08)^{\mathrm{a}}$ & $30,63(0,11)^{\mathrm{a}}$ & & \\
\hline & 4 & $2,343(1,47)^{\mathrm{c}}$ & $2,016(1,47)^{\mathrm{c}}$ & $42,44(1,22)^{a}$ & $41,77(0,35)^{\mathrm{a}}$ & & \\
\hline \multirow[t]{3}{*}{ Control } & & $6,382(0,35)^{\mathrm{a}}$ & $6,015(0,46)^{\mathrm{a}}$ & & & & \\
\hline & & $5,487(0,11)^{b}$ & $5,330(1,24)^{\mathrm{b}}$ & & & & \\
\hline & 0,5 & $4,482(0,12)^{b}$ & $4,732(2,98)^{b}$ & $23,67(1,28)^{\mathrm{b}}$ & $24,99(1,69)^{\mathrm{b}}$ & $11,14^{\mathrm{b}}$ & $11,66^{\mathrm{a}}$ \\
\hline \multirow{3}{*}{$\begin{array}{l}\text { Petroleum } \\
\text { ether }\end{array}$} & $\frac{1}{2}$ & $3,471(2,64)^{b}$ & $4,014(3,56)^{\mathrm{b}}$ & $27,27(3,44)^{\mathrm{b}}$ & $\frac{29,25(2,78)^{b}}{3104(0,66)^{\mathrm{ab}}}$ & & \\
\hline & 3 & $2,668(0,06)^{\mathrm{bc}}$ & $3,111(0,63)^{\mathrm{bc}}$ & $35,64(1,78)^{\mathrm{a}}$ & $31,98(0,08)^{\mathrm{a}}$ & & \\
\hline & 4 & $2,381(1,45)^{\mathrm{c}}$ & $2,521(1,17)^{\mathrm{c}}$ & $38,20(0,88)^{\mathrm{a}}$ & $32,11(1,22)^{\mathrm{a}}$ & & \\
\hline Control & & $6,382(0,35)^{\mathrm{a}}$ & $6,015(0,46)^{\mathrm{a}}$ & & & & \\
\hline \multirow{6}{*}{ Acetone } & & $5,555(0,11)^{b}$ & $5,222(0,03)^{\mathrm{b}}$ & & & & \\
\hline & 0,5 & $4,423(0,03)^{b}$ & $4,670(0,11)^{6}$ & $28,44(1,26)^{b}$ & $26,62(0,66)^{b}$ & $13,31^{\mathrm{a}}$ & $12,67^{\mathrm{a}}$ \\
\hline & 1 & $3,212(1,38)^{\mathrm{b}}$ & $3,880(0,07)^{\mathrm{b}}$ & $29,98(3,24)^{\mathrm{b}}$ & $29,65(0,98)^{\mathrm{b}}$ & & \\
\hline & $\frac{2}{3}$ & $2,885(2,20)^{\mathrm{bc}}$ & $3,111(1,25)^{\mathrm{bc}}$ & $33,19(2,64)^{\mathrm{ab}}$ & $32,46(0,44)^{\mathrm{ab}}$ & & \\
\hline & 3 & $2,452(1,21)^{\mathrm{bc}}$ & $2,623(1,48)^{\mathrm{bc}}$ & $38,57(0,02)^{\mathrm{a}}$ & $37,23(0,22)^{\mathrm{a}}$ & & \\
\hline & 4 & $2,278(0,08)^{\mathrm{c}}$ & $2,484(1,14)^{\mathrm{c}}$ & $46,33(0,84)^{\mathrm{a}}$ & $40,04(0,74)^{\mathrm{a}}$ & & \\
\hline
\end{tabular}

$\mathrm{CG}=$ C. gestroi, $\mathrm{CC}=$ C. curvignathus. Con. $=$ Concentration. Mean $( \pm \mathrm{SD})$ of 5 replicates for each species. Percentage values followed by the same letter are not significantly different in the same group at the 0,05 level of probability. $\mathrm{LC}_{50}=$ Lethal Concentration which causes a $50 \%$ reduction in feeding as compared to the nontreated control.

On the other hand, the $\mathrm{LC}_{50}$ values which is an appropriate measure for determining the toxicity of a chemical has always been questioned before. However, it is a good basis for a preliminary assessment to determine the potential risk of a compound under conditions specified and also it gives an idea to generate on the order of magnitude of the lethal concentration (Duffus 1980).

\section{CONCLUSIONS}

This study shows that the solvents influence the yield and wood extracts properties against subterranean termites; C. curvignathus and C. gestroi. $\mathrm{MeOH}$ solvent had higher extraction yields in every timber species tested. The $\mathrm{MeOH}$ extraction increases the anti-termite activity than $\mathrm{EtOH}$, PETETHR and acetone extraction. A comparative study on field trials is recommended to ascertain the respective needed dose of the extracts. Studies should also be conducted to characterize the chemical compound that causes the durability of a timber against subterranean termites.

\section{ACKNOWLEDGEMENTS}

The authors are extremely grateful to the staff of Wood Entomology Laboratory (Mrs Zaini Soit, Mrs. Zaitihaiza Khamaruddin and Mrs. Norziah Ishak) for helping in collecting termites and preparation of the wood extracts. The study was funded by FRIM Research Project grant (Grant No. 
41310404005).

\section{REFERENCES}

Ahmad-Said, S.; Mohd-Hamami, S. 1982. Responses to wood and wood extractives of Neobalanocarpus heimii and Shorea ovalis by the drywood termites, Cryptotermes cynocephalus (Isoptera: Kalotermitidae). Pertanika 6(3):28-31.

Ahmad Said, S.; Maria, L.T.L.; Faujan, A.; Mohd Hamami, S. 2006. Feeding response of subterranean termite, Coptotermes curvignathus (Isoptera: Rhinotermitidae) to Azadirachta excelsa (Meliaceae) extractives and its timber. Sociobiology 48(2):447-455.

Ahmad Zuhaidi, Y.; Zakaria, I.; Rosdi, K. 2002. Species for timber plantations, in: Krisnapillay B (Ed), A Manual for Forest Plantation Establishment in Malaysia. Malayan Forest Records No. 45. Forest Research Institute Malaysia, Kepong, pp. 13-23.

Arango, A.R.; Green, F.I.; Hintz, K.; Lebow, P.K.; Miller, B.R. 1992. Natural durability of tropical and native woods against termite damage by Reticulitermes flavipes. International Biodeterioration and Biodegradation 57:146-150.

American Society for Testing and Materials. ASTM. 1988. Standard test method of laboratory evaluation of wood and other cellulosic materials for resistance to termites (D3345-88). In: ASTM Annual Book of Standards Vol. 4.10 Wood West Conshohocken, PA, 1988; Vol. 4.10, pp. 430-432.

Banthorpe, D.V.; Charlwood, B.V.; Francis, M.J.O. 1972. The biosynthesis of monoterpenes. Chemical Reviews 72(2):115-155.

Barnes, H.M. 1992. Wood protecting chemicals from the $21^{\text {st }}$ century. International Research Group on Wood Preservation. 24 $4^{\text {th }}$ Annual Conference Meeting at Orlando, Florida, USA, 16-20 May 1992. IRG/WP 93-30018. 29p.

Bashash, M.; Bolandi, M.; Zamindar, N. 2012. Phenolic content of selected sumac fruits from Iran with different solvent. Journal of Chemical Health Risks 2(4):17-20.

Bridgers, E.N.; Chinn, M.S.; Truong, V.D. 2010. Extraction of anthocyanins from industrial purple-fleshed sweetpotatoes and enzymatic hydrolysis of residues for fermentable sugars. Industrial Crops and Products 32:613-620.

Carter, F.L.; Beal, H.R.; Bultman, D.J. 1975. Extraction of antitermitic substances from 23 tropical hardwoods. Wood Science 8:406-410.

Celimene, C.C.; Micales, J.A.; Ferge, L.; Young, R. 1999. Efficacy of pinosylvins against white rot and brown rot fungi. Holzforschung 53:491-497.

Chang, S.T.; Wang, J.H.; Wu, C.L.; Chen, P.K.; Kuo, Y.H. 2001. Comparison of the antifungal activity of cadinane skeletal sesquiterpenoid from Taiwania (Taiwania crypromerioides Hayara) heartwood. Holzforschung 54(3): 241-245.

Chang, S.T.; Cheng, S.S. 2002. Antitermite activity of leaf essential oils and their constituents from Cinnamomum osmophloeum. Journal of Agriculture and Food Chemistry 50:1389-1392.

Delgado-Vargas, F.; Paredes-Lopez, O. 2002. Natural colorants for wood and nutraceutical uses. CRC Press: Boca Raton, FL, USA.

Duffus, J.J. 1980. Environmental toxicology. Edward Arnold Publishers Ltd, London.

Elango, G.; Abdul Rahuman, A.; Kamaraj, C.; Bagavan, A.; Abduz Zahir, A.; Santhoshkumar, T.; Marimuthu, S.; Velayutham, K.; Jayaseelan, C.; Vishnu Kirthi, A.; Rajakumar, G. 2012. Efficacy of medicinal plant extracts agains formosan subterranean termite, Coptotermes formosanus. Industrial Crops and Products 36:524-530. 
Ericsson, T.; Fries, A.; Gref, R. 2001. Genetic correlation of heartwood extractives in Pinus sylvestris progeny tests. Forest Genetics 8(1):73-79.

Fengel, V.D.; Wegener, G. 1989. Wood-chemistry, ultrastructure and reactions. Walter de Gruyter, Berlin. 613p.

Finney, D.J. 1971. Probit analysis, $3^{\text {rd }}$ Edition, London: Cambridge University Press.

Fraga, B.M. 2003. Natural sesquiterpenoids. Natural Product Reports 20(4):392-413.

Golpayegani, A.S., Thevenon, M.F. Gril, J., Masson, E., Pourtahmasi K. 2014. Toxicity potential in the extraneous compounds of white mulberry wood (Morus alba). Maderas. Ciencia y Tecnología 16(2): 227-238.

González-Laredo, R.F.; Rosales-Castro, M.; Rocha-Guzmán, N.E.; Gallegos-Infante, J.A.; Moreno-Jiménez, M.R.; Karchesy, J.J. 2015. Wood preservation using natural products. Madera y Bosques 21(Núm. esp.):63-76.

Haupt, M.; Leithoff, H.; Meier, D.; Puls, J.; Richter, H.G.; Faix, O. 2003. Heartwood extractives and natural durability of plantation-grown teakwood (Tectona grandis L.) - A case study. Holz Roh Werkst 61:473-474.

Hillis, W.E. 1987. Heartwood and tree exudates. Amount of extractives. Springer, Berlin Heidelbery New York. 268p.

Hillis, W.E.; Inoue, T. 1968. The formation of polyphenols in trees-IV: The polyphenols formed in Pinus radiata after Sirex attack. Phytochemistry 7(1):13-22.

Kajdžanoska, M.; Petreska, J.; Stefova, M. 2011. Comparison of different extraction solvent mixtures for characterization of phenolic compounds in strawberries. Journal of Agriculture and Food Chemistry 59 (10): 5272-5278.

Kapasakalidis, P.G.; Rastall, R.A.; Gordon, M.H. 2006. Extraction of polyphenols from processed black currant (Ribes nigrum L.) residues. Journal of Agriculture and Food Chemistry 54:4016-4021.

Kawamura, F.; Sitti Fatimah, M.R.; Othman, S.; Rokiah, H.; Ohara, S. 2011. Antioxidant and antifungal activities of extracts from 15 selected hardwood species of Malaysian timber. European Journal of Wood Products 69:207-212.

Ken, F. 2014. Useful tropical plants database (2014). [online] $<$ http://tropical.theferns.info/ viewtropical.php?id=Anisoptera+laevis $>$. [consulted 8/9/2016].

Khairul, M.; Mohd Noor, M.; Mohamad Omar, M.K.; Abdul Hamid, S.; Mohd Hafiz, M.; Khairul, A.; Izran, K. 2010. Solid wood and veneer study of 12-year-old sesendok clone. Journal of Modern Applied Science 4:1844-1913.

Kilic, A.; Niemz, P. 2010. Extractives in some tropical woods. European Journal of Wood Products 70: 79-83.

Kirker, G.T.; Blodgett, A.B.; Arango, R.A.; Lebow, P.K.; Clausen, C.A. 2013. The role of extractives in naturally durable wood species. International Biodeterioration and Biodegradation 82:53-58.

Kothari, V.; Gupta, A.; Naraniwal, M. 2012. Comparative study of various methods for extraction of antioxidant and antibacterial compounds from plant seeds. Journal of Natural Medicines 12(2):162173.

Lapornik, B.; Prošek, M.; Wondra, A.G. 2005. Comparison of extracts prepared from plant byproducts using different solvents and extraction time. Journal of Food Engineering 71:214-222.

Lim, S.C.; Gan, K.S.; Choo, K.T. 1998. Timber Notes - Heavy Hardwoods (I). Timber Technology 
Bulletin No. 8, ISSN: 139-258.

Lolita, T.; Zanda, K.; Ruta, G. 2012. Comparison of different solvents and extraction methods for isolation of phenolic compounds from horseradish roots (Armoracia rusticana). World Academy of Science. Engineering and Technology 6:1155-1160.

Mburu, F.; Dumarcay, S.; Gérardin, P. 2007. Evidence of fungicidal and termicidal properties of Prunus africana heartwood extractives. Holzforschung 61:323-325.

Mohd Shukari, M. 1982. Malaysia Timber - Sesenduk. Malayan Forest Service Trade Leaflets No.66.

Mori, M.; Aoyama, M.; Hokkaido, S. 1997. Antifungal constituents in the bark of Magnolia obovata. Holz Roh Werkstoff 55:275-278.

Nacimento, M.S.; Santana, A.L.B.D.; Maranhão, C.A.; Oliveira, L.S.; Bieber, L. 2013. Chapter 13 phenolic extractives and natural resistance of wood. In: Biodegradation life of science. Chamy, R. and Rosenkranz, F. (eds). InTech, p 349-370. DOI:10.5772/56358.

Werner, R.A.; Illmann, B.L. 1994. The role of stilbene- like compounds in host tree resistance of Sitka spruce to the spruce beetle, Dendroctonus rufipennis. In: Proceeding, behaviour, population dynamics and control of forest insect conference, 6-11 February 1994, Mani, Hi. OARDC/Ohio State University, Wooster, $\mathrm{OH}$.

Naczk, M.; Shahidi, F. 2004. Extraction and analysis of phenolics in food. Journal of Chromatography A 1054:95-111.

Neya, B.; Hakkou, M.; Petrissans, M.; Gérardin, P. 2004. On the durability of Burkea africana heartwood: evidence of biocidal and hydrophobic properties responsible for durability. Annals of Forest Science 61:277-282.

Ogunwusi, A.A.; Onwuala, A.P.; Ogunsanwo, O.Y. 2013. Comparative analysis of wood properties of Afzelia Africana and Anogeissus leiocarpus growing in Nigeria. Chemistry and Materials Research 3(3):8-12.

Ohmura, W.; Doi, S.; Aoyama, M.; Ohara, S. 2000. Antifeedant activity of flavonoids and related compounds against the subterranean termite Coptotermes formosanus Shiraki. Journal of Wood Science 46:149-153.

Orwa, C.; Mutua, A.; Kindt, R.; Jamnadass, R.; Simons, A. 2009. Agroforestree Database: A tree reference and selection guide version 4.0. [online] $<$ http://www.worldagroforestry.org/af/treedb/>. [consulted 6/6/2016].

Park, C.E.; Baek, N.I.; Park, C.H. 2001. Extrction of panaxynol and panaxyctol compounds from Korean ginseng. Biotechnology and Bioprocess Engineering 6:433-437.

Reyes-Chilpa, R.; Gomez-Garibay, F.; Moreno-Tores, G.; Jimenez-Estrada, M.; QuirozVasquez, R.I. 1998. Flavanoids and isoflavanoids with antifungal properties from Platymiscium yucatanum heartwood. Holzforschung 52:459-462.

Roszaini, K. 2011. Wood extractives as natural preservatives against termites and fungi. $\mathrm{PhD}$ Thesis. University of Bangor.

Roszaini, K.; Hale M.D. 2012. Comparative termite resistance of 12 Malaysian timber species in laboratory tests. Holzforschung 66:127-130.

Roszaini, K.; Rafeadah, R.; Mohd Dahlan, J. 2009. Durability of Malaysian timbers against the Asian subterranean termite Coptotermes gestroi Wasmann. Journal of Institute of Wood Science 19:16-21.

Roszaini, K.; Norazah, M.A.; Mailina, J; Zaini, S.; Mohammad Faridz, Z. 2013. Toxicity and antitermite activity of the essential oils from Cinnamomum camphora, Cymbopogon nardus, Melaleuca 
cajuputi and Dipterocarpus sp. Against Coptotermes curvignathus. Wood Science and Technology 47(6): 1273-1284.

Roszaini, K.; Norazah, M.A.; Zaini, S.; Zaitihaiza, K. 2014. Anti-termitic potential of heartwood and bark extract and chemical compounds isolated from Madhuca utilis Ridl. H. J. Lam and Neobalanocarpus heimi King P. S. Ashton. Holzforschung 68(6):713-720.

Roszaini, K.; Khairul, A.; Zaitihaiza, K.; Zaini, S. 2015. Chemical compositions and termiticidal activities of the heartwood from Calophyllum inophyllum L. Anais da Academia Brasileira de Ciências 87(2):743-751.

Rudman, P. 1965. The cause of natural durability in timber. XVIII. Further notes on the fungi toxicity of wood extractives. Holzforschung 19:57-58.

Scheffer, T.C.; Cowling, E.B. 1966. Natural resistance of wood to microbial deterioration. Annual Review of Phytopathology 4:147-168.

Shanbhag, R.R.; Sundararaj, R. 2013. Physical and chemical properties of some imported woods and their degradation by termites. Journal of Insect Science 13:63.

Spigno, G.; Tramelli, L.; De Faveri, D.M. 2007. Effects of extraction time, temperature and solvent on concentration and antioxidant activity of grape marc phenolics. Journal of Food Engineering 81(1):200-208.

Steller, S.D.; Labosky, P. 1982. Antitermitic properties of cellulose pads treated with bark extractives. Wood Fiber Science 65(18):107-114.

Syofuna, A.; Banana, A.Y.; Nakabonge, G. 2012. Efficiency of natural wood extractives as wood preservatives against termite attack. Maderas Ciencia y Tecnología 14(2):155-163.

Tascioglu, C.; Yalcin, M.; Troya, T.D.; Sivrikaya, H. 2012. Termiticidal properties of some wood and bark extracts used as wood preservatives. Bioresources 7(3):2960-2969.

Taylor, A.M.; Gartner, B.L.; Morrell, J.J. 2006. Effects of heartwood extractive fractions of Thuja plicata and Chamaecyparis nootkatensison wood degradation by termites or fungi. Journal of Wood Science 52: 147-153.

Wang, Q.A.; Zhou, B.; Shan, Y. 2004. Progress on antioxidant activation and extracting technology of flavonoids. Chemical Products and Technology 11:29-33.

Watanabe, Y.; Mihara, R.; Mitsunaga, T.; Yoshimura, T. 2005. Termite repellent sesquiterpenoids from Callitris glaucophylla heartwood. Forest Ecology and Management 258:1918-1923.

Werner, R.A.; Illmann, B.L. 1994. The role of stilbene- like compounds in host tree resistance of Sitka spruce to the spruce beetle, Dendroctonus rufipennis. In: Proceeding, behaviour, population dynamics and control of forest insect conference, 6-11 February 1994, Mani, Hi. OARDC/Ohio State University, Wooster, $\mathrm{OH}$.

Windeisen, E.; Wegener, G.; Lesnino, G.; Schumacher, P. 2002. Investigation of the correlation between extractives content and natural durability in 20 cultivated larch trees. Holz Roh Werkstoff 60:373-374.

Wood Identification. 2010. Properties and uses Merawan.[online]. <https://info.frim.gov.my/ woodid/Properties_detail.cfm?Name=Merawan $>$ [consulted 5/10/2016].

Wu, C.L.; Chien, S.C.; Wang, S.Y., Ku, Y.H.; Chang, S.T. 2005. Structure-activity relationships of cadinane-type sesquiterpene derivatives against wood decay fungi. Holzforschung 59:620-627.

Yuan, Z.; Hu, X.P. 2011. Evaluation of differential antitermitic activities of Lantana camara oven-dried tissues against Reticulitermes virginicus (Isoptera: Rhinotermitidae). Journal of the Indian Institute of Science 18:671-681. 